\title{
EFEKTIVITAS PROGRAM KELUARGA HARAPAN TERHADAP PEMBERDAYAAN MASYARAKAT DI DESA KANIE KECAMATAN MARITENGNGAE KABUPATEN SIDENRENG RAPPANG
}

\author{
${ }^{1)}$ Hastirani, ${ }^{2}$ Kamaruddin Sellang, ${ }^{3)}$ Lukman \\ Fakultas IImu Sosial dan Politik Universitas Muhammadiyah Sidenreng Rappang \\ hastirani43172030inter@gmail.com \\ kamaruddinsellangg@gmail.com \\ lukmansirap75@gmail.com
}

\begin{abstract}
Abstrak
Penelitian ini bertujuan untuk mengetahui Efektivitas Program Keluarga Harapan terhadap Pemberdayaan Masyarakat di Desa Kanie Kecamatan Maritengngae Kabupaten Sidenreng Rappang dan untuk mengetahui Faktor-Faktor yang Memengaruhi Efektivitas Program Keluarga Harapan di Desa Kanie Kecamatan Maritengngae Kabupaten Sidenreng Rappang. Populasi dalam penelitian ini adalah 91 Keluarga Penerima Manfaat Program Keluarga Harapan di Desa Kanie dimana pengambilan sampel menggunakan teknik sampling jenuh dengan rumus Arikunto yaitu mengambil seluruh subjek jika kurang dari 100 orang, sehingga sampelnya berjumlah 91 orang. Teknik pengumpulan data yang digunakan dalam penelitian ini adalah observasi, kajian kepustakaan, dan kusioner/angket. Teknik analisis data yang digunakan adalah statistik deskriptif dengan skala likert dan tabel frekuensi, uji kualitas data dengan SPSS. Hasil penelitian ini menunjukkan bahwa Efektivitas Program Keluarga Harapan terhadap Pemberdayaan Masyarakat di Desa Kanie dengan nilai persentase sebesar 82\% dikategorikan "Sangat Baik". Adapun faktorfaktor yang memengaruhi efektivitas Program Keluarga Harapan diantaranya: Sasaran $(89,6 \%)$, Koordinasi $(89,4)$, Sosialisasi $(91,4 \%)$, dan Jumlah bantuan $(77,4 \%)$.
\end{abstract}

Kata Kunci: Efektivitas, Pemberdayaan Masyarakat

\begin{abstract}
This study aims to determine the Effectiveness of the Family Hope Program on Community Empowerment in Kanie Village, Maritengngae District, Sidenreng Rappang Regency and to determine the Factors Influencing the Effectiveness of the Family Hope Program in Kanie Village, Maritengngae District, Sidenreng Rappang Regency. The population in this study were 91 Beneficiary Families of the Family Hope Program in Kanie Village where the sampling used a saturated sampling technique with the Arikunto formula, namely taking all subjects if less than 100 people, so that the sample amounted to 91 people. Data collection techniques used in this study were observation, literature review, and questionnaires. The data analysis technique used is descriptive statistics with Likert scale and frequency tables, data quality test with SPSS. The results of this study indicate that the effectiveness of the Family Hope Program on Community Empowerment in Kanie Village with a percentage value of $82 \%$ is categorized as "Very Good". The factors that influence the effectiveness of the Family Hope Program include: Target (89.6\%), Coordination (89.4), Socialization (91.4\%), and Amount of assistance (77.4\%).
\end{abstract}

Keywords: Effectiveness, Community Empowerment

JIA | Volume 9 | Nomor 2 | Edisi Agustus 2021 


\section{A. PENDAHULUAN}

Pemerintah sebagai pemegang kekuasaan tertinggi berperan penting dalam mencapai tujuan negara. Berdasarkan Undang-Undang Dasar Tahun 1945, tujuan Negara Kesatuan Republik Indonesia telah dituangkan pada alinea ke empat yang berbunyi "Melindungi segenap bangsa dan seluruh tumpah darah Indonesia, memajukan kesejahteraan umum, mencerdaskan kehidupan bangsa, dan ikut melaksanakan ketertiban dunia yang berdasarkan kemerdekaan, perdamaian abadi, dan keadilan sosial".

Indonesia merupakan negara berkembang dengan jumlah populasi yang besar. Indonesia menduduki posisi ke empat jumlah penduduk terbesar di dunia. Berdasarkan Data Kependudukan Semester 1 per tanggal 30 Juni 2020, total penduduk Indonesia sebesar 268.583.016 jiwa. Populasi sebesar ini menyebabkan Indonesia memiliki banyak masalah, salah satunya kemiskinan. Oleh karena itu diperlukan upaya yang secara komprehensif dapat menanggulangi masalah kemiskinan. Dalam hal ini pemerintah harus menempuh strategi, yaitu dengan; (1) Memenuhi kebutuhan pokok keluarga dan kelompok masyarakat miskin agar mereka terlindungi, dan (2) Mengembangkan kemampuan mereka dalam melakukan usaha melalui pemberdayaan, sehingga dapat mencegah munculnya kemiskinan baru.

Upaya pemerintah dalam mengatasi permasalahan kemiskinan diatur dalam Undang-Undang Nomor 13 Tahun 2011 tentang Penanganan Fakir Miskin. Peraturan ini menjelaskan bahwa pemerintah bertanggung jawab dalam melakukan suatu upaya dengan membentuk suatu kebijakan atau program yang dapat membantu warga negara dalam memenuhi kebutuhan dasar seperti pendidikan, kesehatan, pangan, sandang, perumahan, pekerjaan, dan pelayanan sosial.

Pemerintah Indonesia meluncurkan Program Keluarga Harapan (PKH) melalui departemen sosial pada tahun 2007 sebagai pengembangan kebijakan dan percepatan penanggulangan kemiskinan dalam bidang perlindungan sosial. $\mathrm{PKH}$ merupakan program bantuan sosial bersyarat yang diperuntukkan bagi keluarga miskin dan rentan yang sebelumnya terdaftar dalam data terpadu penanganan fakir miskin yang diolah
p-ISSN 2302-0970

e-ISSN 2723-0201

oleh pusat data dan informasi kesejahteraan sosial, kemudian ditetapkan menjadi Keluarga Penerima Manfaat (KPM). Landasan hukum Program Keluarga Harapan yaitu Peraturan Menteri Sosial Republik Indonesia Nomor 1 Tahun 2018 tentang Program Keluarga Harapan.

Tujuan PKH termuat dalam Peraturan Menteri Sosial Nomor 1 Tahun 2018 pasal 2 sebagai berikut:

1. Untuk meningkatkan taraf hidup Keluarga Penerima Manfaat (KPM) melalui akses layanan pendidikan, kesehatan, dan kesejahteraan sosial.

2. Mengurangi beban pengeluaran dan meningkatkan pendapatan keluarga miskin dan rentan.

3. Menciptakan perubahan perilaku dan kemandirian Keluarga Penerima Manfaat (KPM) dalam mengakses layanan kesehatan dan pendidikan serta kesejahteraan sosial.

4. Mengurangi kemiskinan dan kesenjangan.

5. Mengenalkan manfaat produk dan jasa keuangan formal kepada Keluarga Penerima Manfaat (KPM).

Selain Program Keluarga Harapan, pemerintah juga meluncurkan beberapa program bantuan lainnya seperti RASKIN, BLT, dan sebagainya. Namun programprogram tersebut belum sepenuhnya dapat menyelesaikan permasalahan kemiskinan. Tingginya angka kemiskinan menggambarkan bahwa upaya-upaya yang dilakukan pemerintah dengan membentuk program-program tersebut belum efektif atau belum berhasil untuk mengentaskan kemiskinan. Hal ini terlihat dari meningkatnya angka kemiskinan di Indonesia. Jumlah penduduk miskin pada Maret 2020 setara dengan $9,78 \%$ jumlah penduduk yang mencapai 26,42 juta jiwa. Jika dibandingkan dengan angka pada September 2019 persentasenya meningkat dari $9,22 \%$. Pada Maret 2020 penduduk miskin bertambah 1,63 juta jiwa jika dilihat dari jumlahnya. Naik 6,6\% jika dibandingkan angka pada September 2019 (BPS, 2020).

Program Keluarga Harapan dijadikan sebagai tulang punggung upaya penanggulangan kemiskinan yang dapat bersinergi dengan program perlindungan dan pemberdayaan. Maka pemerintah bertanggung jawab dalam memberi kekuatan/power kepada orang yang kurang 
mampu atau miskin/powerless dan memperoleh dukungan penuh tidak hanya dari masyarakat yang menjadi kelompok sasaran tapi juga dari berbagai pihak.

Program ini telah berjalan, namun dalam pelaksanaannya masih ditemukan berbagai permasalahan. Berdasarkan observasi awal yang dilakukan di Desa Kanie, ditemukan masalah mengenai KPM (Keluarga Penerima Manfaat) yang tidak tepat sasaran. KPM seharusnya merupakan keluarga miskin dan rentan, sedangkan yang terjadi adalah bantuan diberikan kepada keluarga yang mampu, sementara ada masyarakat yang layak menerima namun tidak diberikan bantuan. Kedua, KPM belum sepenuhnya mengalokasikan bantuan sesuai aturan, masih ditemukan adanya KPM yang menggunakan dana di luar tujuan program yang tidak sesuai dengan aturan $\mathrm{PKH}$, seperti menggunakan dana untuk meningkatkan gaya hidup. Ketiga, pendistribusian bantuan pangan terkadang tidak tepat waktu. Sehingga bantuan komplementer yang seharusnya diberikan dalam sekali sebulan kadang diterima bersamaan dengan bantuan pangan untuk bulan berikutnya.

Berdasarkan permasalahan di atas, penulis tertarik untuk melakukan penelitian dengan judul "Efektivitas Program Keluarga Harapan terhadap Pemberdayaan Masyarakat di Desa Kanie Kecamatan Maritengngae Kabupaten Sidenreng Rappang". Adapun tujuan penelitian ini untuk mengetahui bagaimana Efektivitas Program Keluarga Harapan terhadap Pemberdayaan Masyarakat di Desa Kanie Kecamatan Maritengngae Kabupaten Sidenreng Rappang dan faktor-faktor apa yang memengaruhi Efektivitas Program Keluarga Harapan terhadap Pemberdayaan Masyarakat di Desa Kanie Kecamatan Maritengngae Kabupaten Sidenreng Rappang.

Efektif berasal dari kata bahasa Inggris yaitu effective yang artinya berhasil atau sesuatu yang dilakukan berhasil dengan baik. Kamus ilmiah populer mendefinisikan efektivitas dengan ketepatan penggunaan, hasil guna, atau menunjang tujuan, sedangkan secara umum pengertian efektivitas menunjukkan seberapa jauh tercapainya tujuan yang terlebih dahulu ditentukan.
p-ISSN 2302-0970

e-ISSN 2723-0201 mendefinisikan bahwa efektivitas adalah suatu ukuran yang menggambarkan seberapa jauh pencapaian target. Sejalan dengan Hidayat (Samad, 2017) merumuskan efektivitas sebagai ukuran sejauh mana pencapaian target yang mencakup kuantitas, kualitas, dan waktu, tingginya efektivitas menunjukkan besarnya persentase target yang telah dicapai.

Sutrisno Edi (Astari \& Prambudi, 2018) menyimpulkan bahwa dari berbagai pendapat dan teori mengenai efektivitas, perlu diperhatikan beberapa indikator dalam mengukur efektivitas suatu kegiatan atau aktivitas, yaitu sebagai berikut;

1. Pemahaman program, yaitu indikator yang digunakan untuk mengukur sejauh mana pengetahuan masyarakat terhadap Program Keluarga Harapan. Pemahaman program kepada masyarakat dapat dilakukan dengan kegiatan sosialisasi.

2. Tepat sasaran, dalam pelaksanaan suatu program ketepatan sasaran sangatlah diperlukan. Ketepatan sasaran program dilihat dari sejauhmana peserta program tepat dengan sasaran yang sudah ditentukan sebelumnya.

3. Tepat waktu, ketepatan waktu dalam pencairan dana bantuan $\mathrm{PKH}$ sangat penting, mengingat pencairan dana bantuan sosial harus sesuai dengan jadwal dan waktu yang telah ditentukan.

4. Tercapainya tujuan, kesesuaian antara hasil pelaksanaan program dengan tujuan program yang telah ditetapkan sebelumnya dapat menunjukkan tujuan program. Perbandingan antara input dan output yang dihasilkan menggambarkan tercapainya tujuan atau tidak.

5. Perubahan nyata, bentuk perubahan setelah pelaksanaan kegiatan atau program yang dapat dirasakan oleh seseorang atau kelompok.

Berdasarkan uraian di atas dapat diketahui bahwa efektivitas merupakan konsep yang begitu penting karena dapat memberikan gambaran mengenai keberhasilan suatu organisasi, program atau kegiatan dalam mencapai sasarannya. Maka, dapat disimpulkan bahwa efektivitas merupakan tingkat ketercapaian tujuan.

Menurut Suharto (Najidah \& Lestari, 2019) faktor-faktor yang memengaruhi efektivitas program terdiri dari 4 kriteria, sebagai berikut: 
1. Sasaran, sasaran merupakan faktor penting dalam proses pelaksanaan program, karena memberikan ukuran berhasil atau tidaknya suatu program yang telah dilaksanakan. Ketepatan sasaran program dilihat dari sejauhmana peserta program tepat dengan sasaran yang sudah ditentukan sebelumnya.

2. Koordinasi, koordinasi merupakan suatu hal penting yang menjadi penentu berhasil atau tidaknya program. Koordinasi merupakan kegiatan yang dilakukan oleh berbagai pihak untuk saling mengatur atau menyepakati sesuatu.

3. Sosialisasi, hal yang sangat penting untuk diperhatikan dalam kegiatan sosialisasi yaitu kemampuan penyelenggara program dalam melakukan sosialisasi program sehingga informasi mengenai pelaksanaan program dapat tersampaikan kepada masyarakat.

4. Jumlah bantuan, jumlah pendistribusian bantuan kepada keluarga miskin yang selanjutnya ditetapkan sebagai peserta program, dalam pendistribusian bantuan perlu diperhatikan pemerataannya.

Pemberdayaan berasal dari kata dasar "daya" yang dalam bahasa inggris adalah "empowerment" berarti "kekuatan". Pemberdayaan berarti memberi daya kepada kelompok lemah yang belum mempunyai daya atau kekuatan untuk hidup secara mandiri, terutama dalam memenuhi kebutuhan pokok/kebutuhan dasar hidup mereka sehari-hari, seperti makanan, pakaian/sandang, rumah/papan, pendidikan, kesehatan, dan sebagainya.

Proses pemberdayaan merujuk kepada tindakan nyata yang dilakukan secara berjenjang untuk melakukan perubahan atau mengubah keadaan pada masyarakat. Terkait hal ini, Sumadyo dalam Mardikanto dan Soebiato (2017) menyebutkan Tri Bina dalam pemberdayaan masyarakat yang dikenal dengan bina manusia, bina usaha, dan bina lingkungan. Mardikanto juga menambahkan akan pentingnya suatu kelembagaan, karena pemberdayaan masyarakat sebagai suatu proses yang pada hakikatnya adalah proses pengembangan kapasitas (Mustanir, Samad, Jabbar, Ibrahim, \& Juniati, 2019).

1. Bina manusia, pengembangan kapasitas manusia (bina manusia) adalah hal utama dalam upaya pemberdayaan yang
p-ISSN 2302-0970

e-ISSN 2723-0201

seharusnya diperhatikan. Disimpulkan bahwa bina manusia ialah salah satu upaya dalam pemberdayaan masyarakat yaitu dengan meningkatkan kualitas sumber daya manusia.

2. Bina usaha, pengembangan kapasitas usaha (bina usaha) adalah proses pemberdayaan, karena pengembangan kapasitas manusia yang tidak memberi manfaat terhadap perbaikan kesejahteraan tidak akan berhasil. Maka dapat simpulkan bahwa bina usaha merupakan suatu upaya yang dilakukan untuk memperbaiki kesejahteraan hidup masyarakat.

3. Bina lingkungan, pengembangan kapasitas lingkungan (bina lingkungan) sangat diperlukan karena dapat mengarah pada ketamakan atau kerakusan yang bisa merusak lingkungan jika bina usaha tidak terkendali. Selama ini lingkungan dimaknai hanya sekedar lingkungan fisik, namun dalam praktiknya, perlu disadari bahwa lingkungan sosial juga sangat berpengaruh terhadap keberlanjutan bisnis dan kehidupan.

4. Bina kelembagaan, pengembangan kapasitas kelembagaan (bina lembaga), kelembagaan seringkali dimaknai sebagai beragam bentuk lembaga (kelompok/organisasi) dalam arti sempit. Dapat disimpulkan bahwa bina kelembagaan merupakan pembentukan atau perbaikan suatu kelompok atau lembaga pemberdayaan masyarakat.

\section{B. METODE PENELITIAN}

Penelitian ini menggunakan metode penelitian deskriptif kuantitatif, dengan dua variabel, variabel pertama yakni efektivitas dan variabel kedua yakni pemberdayaan masyarakat. Dalam penelitian ini yang menjadi populasi adalah $91 \mathrm{KPM}$ (Keluarga Penerima Manfaat) PKH di Desa Kanie Kecamatan Maritengngae Kabupaten Sidenreng Rappang, pengambilan sampel menggunakan teknik sampling jenuh dengan rumus Arikunto yaitu mengambil seluruh subjek jika kurang dari 100 orang, sehingga sampelnya berjumlah 91 orang. Teknik pengumpulan data yang digunakan dalam penelitian ini adalah observasi, kajian kepustakaan, dan kusioner/angket. Teknik analisis data yang digunakan adalah statistik deskriptif dengan skala likert dan tabel frekuensi, uji kualitas data dengan SPSS. 


\section{HASIL DAN PEMBAHASAN}

Model pengujian menggunakan pendekatan corrected item total correlation (korelasi item total dikoreksi) yang digunakan untuk menguji validitas dengan menyusun item-item kuesioner dalam bentuk skala untuk diuji validitas internalnya. Untuk menyatakan valid tidaknya sebuah item, para ahli menentukan batas minimal nilai koefisien korelasi item-total dikoreksi sebesar 0,25 atau 0,30 , maksudnya sama dengan atau lebih besar dari 0,25-0,30.

Program Keluarga Harapan dikatakan efektif ketika hasil dari pelaksanaan program dapat menunjukkan keberhasilan dari segi tercapai tidaknya tujuan yang telah ditetapkan sebelumnya. Efektivitas suatu program dapat dilihat dari:

1. Pemahaman program merupakan pengetahuan yang dimiliki oleh peserta program terkait informasi-informasi pelaksanaan program pada umumnya, hak serta kewajiban peserta program pada khususnya. Dengan pemahaman yang baik akan melahirkan pikiran dan tindakan yang menuntun pada tujuan program.

2. Tepat sasaran merupakan kesesuaian antara peserta program dengan sasaran yang telah ditentukan sebelumnya atau berdasarkan aturan yang telah ditetapkan. Dengan tepatnya peserta program yang berdasarkan kriteria-kriteria sasaran, maka program dapat tepat tertuju kepada yang berhak menerima.

3. Tepat waktu merupakan penggunaan waktu dalam penyaluran bantuan berdasarkan ketentuan program. Pelaksana program harus menjalankan tugas dan fungsinya dengan baik, agar penyaluran bantuan kepada peserta program dapat tersalurkan dalam waktu yang telah ditentukan.

4. Tercapainya tujuan merupakan hasil dari pelaksanaan program sesuai dengan apa yang diharapkan. Dengan proses pelaksanaan program yang berjalan sesuai dengan ketentuan yang sudah ditetapkan, tujuan dari program akan tercapai.

5. Perubahan nyata merupakan bentuk perubahan yang dapat dirasakan oleh peserta program setelah pelaksanaan program dijalankan. Dengan perubahan perilaku peserta program yang mendukung ke arah kesejahteraan menunjukkan bahwa perubahan berdampak positif sehingga tujuan dari program akan tercapai.

Selain itu, untuk memudahkan efektivitas Program Keluarga Harapan, tentu ada faktor-faktor yang memengaruhinya, yaitu sebagai berikut:

1. Sasaran merupakan kriteria-kriteria yang telah ditetapkan untuk peserta program. Dalam pelaksanaan suatu program atau kegiatan penentuan sasaran/peserta program menjadi salah satu faktor penting, dengan adanya kriteria-kriteria tertentu yang telah ditetapkan maka akan memudahkan dalam pemberian bansos, dimana program diperuntukkan untuk keluarga miskin.

2. Koordinasi merupakan kegiatan untuk saling mengatur atau menyepakati suatu hal yang dilakukan oleh berbagai pihak. Dalam proses pengambilan keputusan berbagai perbedaan harus diintegrasikan dengan koordinasi yang baik, pihak-pihak terkait perlu diarahkan dan disatukan agar semua tindakan serta pemikirannya menuju pada tujuan program, maka hasil yang efektif akan tercapai.

3. Sosialisasi merupakan kegiatan penyampaian informasi-informasi terkait pelaksanaan program. Dalam pelaksanaan sosialisasi hal yang perlu diperhatikan adalah kemampuan pelaksana, agar informasi mengenai pelaksanaan program dapat tersampaikan kepada masyarakat.

4. Jumlah Bantuan merupakan jumlah pendistribusian bantuan kepada keluarga miskin yang telah ditetapkan sebagai peserta program. Dalam pendistribusian bantuan perlu diperhatikan pemerataannya di mana keluarga miskin dapat menerima bantuan tanpa terkecuali agar sasaran program dapat tercapai.

Efektivitas serta faktor-faktor yang memengaruhinya baik, tentu dapat meningkatkan pemberdayaan masyarakat melalui PKH yang dapat menunjang pencapaian tujuan program sehingga dapat dikatakan efektif. Pemberdayaan masyarakat dapat dilihat dari:

1. Bina Manusia merupakan upaya pemberdayaan melalui pembinaan atau pelatihan untuk meningkatkan kualitas sumber daya manusia. Dengan adanya pengembangan kapasitas manusia tentunya dapat mengembangkan 
kemampuan setiap individu yang mencakup pengetahuan, sikap, dan keterampilan yang dapat menyejahterahkan masyarakat.

2. Bina Usaha merupakan upaya pemberdayaan melalui pendampingan dalam perbaikan usaha. Dengan adanya pengembangan kapasitas usaha dapat memberikan dampak atau manfaat bagi perbaikan kesejahteraan sehingga usahausaha yang dijalankan efektif.

3. Bina Lingkungan merupakan upaya pemberdayaan melalui pelestarian lingkungan fisik yang menyangkut sumber daya alam dan lingkungan hidup serta lingkungan sosial menyangkut tanggung jawab sosial. Dengan adanya pengembangan kapasitas lingkungan kesejahteraan sosial masyarakat yang tinggal di sekitar lingkungan akan lebih baik.

4. Bina Kelembagaan merupakan upaya pemberdayaan melalui pembentukan atau perbaikan suatu kelompok atau lembaga. Dengan adanya pengembangan kapasitas lembaga dapat memperbaiki individu yang terlibat di dalamnya, tujuan serta aturan lembaga, sehingga kelembagaan yang dibentuk dapat berfungsi secara efektif.

\section{KESIMPULAN}

Berdasarkan hasil penelitian yang telah diuraikan, maka dapat disimpukan:

1. Efektivitas Program Keluarga Harapan terhadap Pemberdayaan Masyarakat di Desa Kanie Kecamatan Maritengngae Kabupaten Sidenreng Rappang dengan nilai persentase sebesar $82 \%$ dikategorikan "Sangat Baik". Indikator efektivitas yang memiliki persentase paling tinggi yaitu pemahaman program $90,8 \%$, sedangkan indikator dengan persentase terendah yaitu tepat waktu $65,2 \%$. Indikator pemberdayaan masyarakat yang memiliki persentase paling tinggi yaitu bina lembaga $90,8 \%$, sedangkan indikator dengan persentase terendah yaitu bina lingkungan $67,8 \%$.

2. Faktor-faktor yang memengaruhi efektivitas Program Keluarga Harapan diantaranya: Sasaran (89,6\%), Koordinasi $(89,4)$, Sosialisasi $(91,4 \%)$, dan Jumlah bantuan $(77,4 \%)$.

\section{E. REFERENSI}

Astari, U. T., \& Prambudi, A. (2018). Efektivitas program keluarga harapan di kecamatan pandak bantul. E-Journal Jurusan IImu Administrasi Negara, 7(5), 692-705. Retrieved from http://journal.student.uny.ac.id/ojs/index .php/adinegara/article/view/12723/1226 1

Hidayat, A. (2018). Efektivitas Pelaksanaan Program Keluarga Harapan (PKH) di Kecamatan Bekasi Timur Kelurahan Margahayu. Public Administration Jurnal (PAJ), 2(2), 212-231. Retrieved from

http://journal.moestopo.ac.id/index.php/ paj/article/view/772

Mustanir, A., Samad, Z., Jabbar, A., Ibrahim, M., \& Juniati. (2019). Kepemimpinan Lurah Terhadap Pemberdayaan Masyarakat $\mathrm{Di}$ Kelurahan Lautang Benteng Kabupaten Sidenreng Rappang. Journal of Social Politics and Governance, 1(2), 20-39. https://doi.org/10.24076/jspg.v1i2.5460

Najidah, N., \& Lestari, H. (2019). Efektivitas Program Keluarga Harapan (Pkh) Di Kelurahan Rowosari Kecamatan Tembalang Kota Semarang. Journal of Public Policy and Management Review, 8(2), $1-17$. https://doi.org/10.14710/jppmr.v8i2.235 14

\section{Dokumen}

Undang-Undang No. 13 Tahun 2011 tentang Penanganan Fakir Miskin

Peraturan Menteri Sosial Republik Indonesia No. 1 Tahun 2018 tentang Program Keluarga Harapan

\section{Internet}

Statistik, Badan Pusat. 2020. "Persentase Penduduk Miskin Maret 2020 naik menjadi 9,78 persen", https://www.bps.go.id/pressrelease/2020/07/1 5/1744/persentase-penduduk-miskin-maret2020-naik-menjadi-9-78-persen.html, diakses pada 22 November 2020 pukul 18.08.

Republika. 2020. "Penduduk Indonesia Capai 268,5 Juta Jiwa", https://republika.co.id/berita/qeyb5h396/keme ndagri-penduduk-indonesia-capai268583016-iwa, diakses pada 23 November 2020 pukul 19.51 . 